\title{
Determination of presence and quantification of cadmium, lead and copper in Nile tilapia (Oreochromis niloticus) fillets obtained from three cold storage plants in the State of Parana, Brazil
}

\author{
Determinação da presença e quantificação dos metais cádmio, chumbo e cobre \\ em filés de tilápia-do-Nilo (Oreochromis niloticus) obtidos de três frigoríficos

\begin{abstract}
Alexandre Nobuhiro TAJIRI ${ }^{1}$, Daisy PONTES NETTO ${ }^{1 *}$, Márcia SASSAHARA ${ }^{1}$, Mari Sylmara Martins RODRIGUES ${ }^{1}$, Cristina Arduini Cavalcanti de ARRUDA ${ }^{1}$
\end{abstract}

\begin{abstract}
Pisciculture is an economic activity that is steadily growing in the state of Parana, Brazil, and Nile tilapia (Oreochromis niloticus) is one of the widely cultivated species in this state. Tilapia is not only a very nutritious food, but also an important indicator of environmental contamination. This study aimed to verify contamination by cadmium, copper and lead in tilapia fillets, and to compare the found values to international legislations. Were collected 135 samples of tilapia fillets, between July 2006 and May 2007, in three fish stores located in regions west and north of Paraná State. Samples of tilapia fillet were analyzed in relation to the presence of cadmiun, lead and copper, using atomic absorption spectrophotometry. Lead has not been detected in the analyses. Cadmium has been detected in three samples, on concentrations of $0.012 \mu \mathrm{g} \cdot \mathrm{g}^{-1}, 0.011 \mu \mathrm{g} \cdot \mathrm{g}^{-1}$ and $0.014 \mu \mathrm{g} \cdot \mathrm{g}^{-1}$. Copper has been detected in all fillets, and the average concentration of each cold storage plant was of $0.122 \mu \mathrm{g} . \mathrm{g}^{-1}, 0.106 \mu \mathrm{g} \cdot \mathrm{g}^{-1}$ and $0.153 \mu \mathrm{g} \cdot \mathrm{g}^{-1}$. The concentrations found in this study are within the limits allowed by both the European and the Australian legislations.
\end{abstract}

Keywords: Brazil; food; spectrophotometry; heavy metals; fish.

\section{Resumo}

A piscicultura é uma atividade econômica em pleno crescimento no Estado do Paraná/Brasil, sendo a tilápia-do-nilo (Oreochromis niloticus) uma das principais espécies de peixe cultivadas no Estado. A tilápia, além de ser um alimento rico, é um importante indicador de contaminação ambiental. O trabalho objetivou a análise dos filés de tilápia para averiguação de contaminação pelos metais cádmio, cobre e chumbo, e a comparação dos valores encontrados com legislações internacionais. Foram coletadas 135 amostras de filés de tilápia, entre julho de 2006 e maio de 2007, de três frigoríficos de peixe localizados nas regiões oeste e norte do Estado do Paraná. As amostras foram analisadas, utilizandose a espectrofotometria de absorção atômica, para averiguar a presença dos metais chumbo, cádmio e cobre. O chumbo não foi detectado nas análises. O cádmio foi detectado em três amostras, uma de cada frigorífico, nas concentrações de $0,012 \mu \mathrm{g} \cdot \mathrm{g}^{-1}, 0,011 \mu \mathrm{g} \cdot \mathrm{g}^{-1} \mathrm{e} 0,014 \mu \mathrm{g} \cdot \mathrm{g}^{-1}$. O cobre foi detectado em todos os filés, sendo as médias de concentração de cada frigorífico de $0,122 \mu \mathrm{g} \cdot \mathrm{g}^{-1}, 0,106 \mu \mathrm{g} \cdot \mathrm{g}^{-1} \mathrm{e} 0,153 \mu \mathrm{g} \cdot \mathrm{g}^{-1}$. As concentrações dos metais encontradas estão de acordo como o permitido pelas legislações europeias e australianas.

Palavras-chaves: Brasil; alimento; espectrofotometria; metais pesados; peixe.

\section{Introduction}

The name "Tilapia" is used to designate fish from the Cichidae family, Perciform Order (HUET, 1983), being commonly used as a reference to the genus Tilapia, Sarotherodon and Oreochromis, and mainly to the species of greater size and with potential for fishing, breeding and consumption (McANDREW, 2000).

The most cultivated species of tilapia in the world is Oreochromis niloticus, commonly known as Nile tilapia or Nilotic tilapia (KUBITZA, 2000). This is a robust species, presenting high prolificity, resistance to high temperatures and low respiratory demand. It is also a plankton eater, omnivore and mouth brooding fish (BEVERIDGE; BAIRD, 2000; HUET, 1983;
KUBITZA, 2000; OSTRENSKY; BOEGUER, 1998; POPMA; MASSE, 1999; TURNER; ROBINSON, 2000).

The relevance of fish as a source of protein is undeniable, and so is its role as an indicator of environmental contamination. Fish are excellent sources for eco-toxicological studies due to their ability of removing, storing and bio-accumulating polluting composts in their organisms (STREIT, 1998).

Nowadays, there are many contaminants being discharged into nature by human actions, and among these there are also toxic metals. Metals, among other criteria, can not be synthesized nor destroyed by men, and are released into the environment in geologic processes, such as rain, erosion and also

Received 15/4/2009

Accepted 23/1/2010 (004164)

Veterinary Toxicology and Toxic Plants Laboratory, Preventive Veterinary Medicine Department, Agrarian Sciences Center, State University of Londrina, Rod. Celso Garcia Cid, s/n, Km 445, Bairro Perobal, CP 6001, CEP 86051-990, Londrina, PR, Brazil, E-mail: rnetto@uel.br

${ }^{*}$ Corresponding autor 
by human activities, such as mining and metallurgy (GOYER; CLARKSON, 2001).

With the increase of global demand for food and the expansion of rural borders, the human being has been more and more concerned with his health and the environment where he lives. In this study, analyses were conducted in order to verify the presence and level of contamination on tilapia fillets (Oreochromis niloticus) by copper, cadmium and lead.

No other similar study has been conducted in the state of Parana, Brazil, since it has the aim of analyzing fillets from tilapias collected in cold storage plants, adopting a posture of vigilance towards the quality of food consumed by the population.

The study aimed to analyze tilapia fillets in order to identify contamination by cadmium, copper and lead, and to compare possible values found in the study to international legislation.

\section{Materials and methods}

\subsection{Collection areas and sampling}

Collection was conducted in three fish cold storage plants in the State of Parana, Brazil, contacted by the State Agriculture and Supply Secretary (SEAB).

The cold storage plants were chosen by their economic importance in their areas and are named by the letters A, B and C. Cold storage plant A is located in the western area of the state and is federally inspected. Cold storage plants B and $\mathrm{C}$ are located in the northern region of the state and are under municipal inspection services. Cold storage plant $\mathrm{A}$ has an average slaughtering of 30 tons per week and cold storage plant B and $\mathrm{C}$ of $600-1000 \mathrm{Kg}$ of tilapia weekly.

The number of samples collected was calculated according to the standard established by Cannon, Roe (1982). In each cold storage plant, 45 tilapia (Oreochromis niloticus) fillet samples were collected, making up a total of 135 samples being analyzed. Three visits were conducted in each place, with the collection of 15 samples at random, at the end of the processing phase, before packaging, in each visit. The samples were collected in the period between July, 2006 and May, 2007.

\subsection{Collection protocols}

The collected samples were stored in plastic bags and kept under refrigeration in thermal bags, from the collection point until the Veterinary Toxicology and Toxic Plant Laboratory (Preventive Veterinary Medicine Department at 'Londrina' State University).

Before storage and analysis, the fillets were weighed and approximately $50 \mathrm{~g}$ of each fillet was kept for sampling. The samples were wrapped in PVC film, numbered and frozen at $-20^{\circ} \mathrm{C}$.

\subsection{Material analysis}

The analyses of tilapia fillets were performed in the Toxicology Assistance Center from 'Paulista' State University
"Júlio de Mesquita Filho" (UNESP - Botucatu Campus), a national reference center for toxicological analyses.

In order to determine the concentration of metals, three grams of Nile tilapia fillet were weighed and placed in $6 \mathrm{~mL}$ of nitric acid (HNO3-65\%) in oxaflon reaction glass, for humid mineralization (BASSET; DENNEY; JEFFERY, 1981).

Humid mineralization was performed in processed microwave oven (PROVECTO DGT - 100 PLUS), following the manufacturer's manual. Twelve samples were mineralized at a time.

Readings were made under atomic absorption spectrophotometry, in the E.A.A - GBC AA 932 equipment, under optimized conditions according to the manufacturer's recommendations (ATHANASOPOULOS, 1994).

For copper, cadmium and lead readings, light bulbs with the following amperage and wavelength were used: $6.0 \mathrm{~mA}$ and $324.7 \mathrm{~nm}$; of $5.0 \mathrm{~mA}$ and $228.8 \mathrm{~nm} ; 9.0 \mathrm{~mA}$ and $283.3 \mathrm{~nm}$, respectively.

Detection and quantification limits for copper, cadmium and lead were: 0.025 and $0.50 \mu \mathrm{g} . \mathrm{g}^{-1} ; 0.009$ and $0.10 \mu \mathrm{g} . \mathrm{g}^{-1} ; 0.05$ and $0.20 \mu \mathrm{g} \cdot \mathrm{g}^{-1}$, respectively.

\subsection{Calculations and statistical analyses}

Calculations were adapted from World Health Organization (WHO, 1997). In order to calculate the Weekly Theoretical Maximum Intake allowed for cadmium, the formula WTMIEU $=\mathrm{P} \times$ TAWD, where $\mathrm{P}$ is the weight of an adult, established in $60 \mathrm{Kg}$, and TAWD is the Temporary Admissible Weekly Dose recommended by the REGULATION (EC) N. 1881/2006 from the European Union of $7 \mu \mathrm{g} \cdot \mathrm{Kg}^{-1}$. It should be observed that WTMIEU is equal $420 \mu \mathrm{g}$ cadmium.

In order to calculate the Weekly Theoretical Intake of Fish in Brazil (WTIFi) the formula WTIFi $=$ DTIFi $\times$ DW was used, where DTIFi stands for the Daily Theoretical Intake of Fish, established in $16.5 \mathrm{~g}$ (EMBRAPA, 2001), and DW are the seven days of the week. From this formula, it can be established that the WTIFi is equals $116 \mathrm{~g}$.

In order to calculate the Weekly Theoretical Intake of Contaminant by adults (WTIC), the mathematical formula WTIC $=\mathrm{C} \times$ WTIFi was used, where $\mathrm{C}$ is the highest value of cadmium found in this research. Cadmium WTIC is of $1.62 \mu \mathrm{g}$.

The statistical analyses of the values of copper found in the three cold storage plants were performed in the Excel program. The means value and the standard deviation are presented in Table 1 . In the variation analysis, the value of ' $\mathrm{p}$ ' was 0.0003 .

\section{Results and discussion}

Cadmium was found in three samples of tilapia fillets, one from each collection area. The sample from cold storage plant A presented a concentration of $0.012 \mu \mathrm{g} . \mathrm{g}^{-1}$ of this metal, while the sample from cold storage plant B presented $0.011 \mu \mathrm{g} . \mathrm{g}^{-1}$ and the one from cold storage plant $C$ was $0.014 \mu \mathrm{g} . \mathrm{g}^{-1}$. 
During the cultivation of the tilapias, cadmium could have been acquired directly from the water or by the consumption of contaminated food (STREIT, 1998). Food, despite being a possible source of contamination, is not the probable source for this metal. In the State of Parana, the cultivation systems are those called intensive and super intensive, where feeding is based on the usage of feed (ZIMMERMANN; FITZSIMMONS, 2004). In other words, contamination on feed would possibly cause a more homogeneous concentration of contamination in the tilapia batches analyzed. According to the authors Cannon \& Roe (1982), the sampling conducted implies that finding one positive sample represents a condition where approximately $3 \%$ of the total population is contaminated, reinforcing the possibility of the contaminant not being from a common origin to all the individuals, as it is the case with food.

Çoğun et al. (2003) showed that Nilotic tilapias bioconcentrate cadmium when submitted to environments contaminated with the metal. Allinson et al. (2002) analyzed Oreochromis mossambicus from reservoirs in the south of Sri Lanka, and found a contamination pattern similar to the one found in this study, only some individuals had the presence of cadmium in the analysis, with the suspicion that the metal was originated in the environment. Several factors influence the bioconcentration of metals. However, the individual sanity should be highlighted. The health condition of the animal influences the absorption of contaminants. According to Bols et al. (2001), exposure to heavy metals cause lesions in branchiae, generating a seizure in the protective barrier of this organ, leaving the fish susceptible to the entrance of contaminants by these means. According to Chasin, Pedrozo (2003), branchial lesion generates an increase in the oxygen demand, compensated by an increase in the branchial activity and consequently an increase in the bioconcentration of contaminants, such as metals. These studies reinforce the idea that the levels of cadmium found in this paper might have been originated from the environment.

The cadmium found in the tree samples might have several origins, but its presence implies a risk factor for human health. According to Goyer, Clarkson (2001), this metal enters the human organism mainly through the consumption of food.

Observing the result obtained for WTMIEU and comparing this value with the one found for WTIC, one can find the theoretical intake of cadmium, based on the greatest value found for contamination, that is approximately 260 times lower than the maximum limit for weekly intake of the metal ( $7 \mu \mathrm{g} \cdot \mathrm{Kg}^{-1}$ of live weight) advised by the European Union.
All copper samples were considered positive. The property means and maximum and minimum found values are presented in Table 1.

Çoğun et al. (2003) demonstrated that in Nile tilapias $(17-19 \mathrm{~cm})$ submitted to environments containing $1 \mathrm{ppm}$ copper, when obtaining fillets after 30 days, a concentration of approximately $6.20 \mu \mathrm{g} \cdot \mathrm{g}^{-1}$ of the metal was found. Comparing the value of $6.20 \mu \mathrm{g} \cdot \mathrm{g}^{-1}$ to the value found in the means from the analyzed samples, and knowing that the tilapia season in Brazil is of approximately 4 to 8 months (ZIMMERMANN; FITZSIMMONS, 2004), it can be inferred that the environment where the fish were cultivated may present a much lower level of copper contamination than $1 \mathrm{ppm}$. In contaminated environments, copper can be found bio-accumulated in tilapias in very high concentrations. Birungi et al. (2007) exposed 240 samples of Nile tilapia to areas that were known to be contaminated in Lake Vitoria, Uganda, and after six weeks they found values of copper in the animals' muscles reaching concentrations of 10,000 $\mu \mathrm{g} \mathrm{Cu} . \mathrm{g}^{-1}$ muscle.

Allinson et al. (2002) collected Oreochromis mossambicus from reservoirs in the south of Sri Lanka and found a variation in the level of copper, in fillets from the fish, from $0.5 \mu \mathrm{g} . \mathrm{g}^{-1}$ to $1.2 \mu \mathrm{g} . \mathrm{g}^{-1}$. Oyewale, Musa (2006) detected copper in Nilotic tilapia from the Kainji and Jeba lakes (Nigeria). The average levels of copper found in these fillets were of $2 \mu \mathrm{g} \cdot \mathrm{g}^{-1}$ (Kainji) and $3 \mu \mathrm{g} \cdot \mathrm{g}^{-1}$ (Jeba). In the mentioned papers, the samples were collected from the wild, and the values found were greater than the means copper found in the Nilotic tilapia collected at the cold storage plants. Factors leading to these differences are yet uncertain, although the environmental pressure suffered by the samples collected in Sri Lanka and Nigeria is possibly greater than the pressure suffered by samples collected from the cold storage plants, since the latter were obtained from fish farms where, according to Meschkat (1975), fish breeding and some other environmental factors are controlled by men.

Copper is a nutritionally essential element for the human body in that it participates in several biochemical reactions of the body and acts as a constitution of organic enzymes (metaloenzymes). Normal levels of this metal in human serum are between 120 and $145 \mu \mathrm{g} . \mathrm{L}^{-1}$ (GOYER; CLARKSON, 2001).

According to WHO (2004), the daily intake of copper for adults should be of a minimum of $900 \mu \mathrm{g}$, for children up to three years old of $340 \mu \mathrm{g}$, for children between 4 and 8 years old of $440 \mu \mathrm{g}$, between 9 and 13 of $700 \mu \mathrm{g}$ and from 14 to 18 of $890 \mu \mathrm{g}$. During pregnancy and breastfeeding, the daily intake of at least $1000 \mu \mathrm{g}$ and $1300 \mu \mathrm{g}$ copper, respectively, is recommended.

Table 1. Minimum, maximum, means and standard deviation values for copper found in 135 samples of tilapia fillets (Oreocromis niloticus), analyzed in atomic absorption spectrophotometer, from three fish warehouses in the State of Parana, with collections being made between May, 2006 and July, 2007.

\begin{tabular}{|c|c|c|c|c|}
\hline Warehouses & $\begin{array}{l}\text { Minimum value found for copper } \\
\qquad\left(\mu \mathrm{g} . \mathrm{g}^{-1}\right)\end{array}$ & $\begin{array}{l}\text { Maximum value found for copper } \\
\left(\mu \mathrm{g} \cdot \mathrm{g}^{-1}\right)\end{array}$ & $\begin{array}{l}\text { Means for the copper values found } \\
\left(\mu \mathrm{g} \cdot \mathrm{g}^{-1}\right)\end{array}$ & Standard deviation \\
\hline B & 0.067 & 0.260 & 0.111 & 0.028 \\
\hline
\end{tabular}


The values found for copper are within what is recommended by the Food Standards Australia New Zealand (2002), $200 \mu \mathrm{g}$ copper per Kg live weight per day. This value is standardized by the World Health Organization.

Analyzing the means statistic results for copper from the cold storage plants $\mathrm{A}, \mathrm{B}$ and $\mathrm{C}$ together, it could be noticed that there was a significant difference among the three of them. However, when analyzed by blocks, it could be observed that there was no difference between A and B, but between A and C, and also between $\mathrm{B}$ and $\mathrm{C}$. The average copper contamination from cold storage plant $C$ was greater than those found in both $\mathrm{A}$ and $\mathrm{B}$. this generated a significant difference when analyzed in group, however, no results were found to be above that permitted by the Australian legislation.

Lead was not detected in any of the samples collected. This result is in accordance with the REGULATION (EC) N. $1881 / 2006$ from the European Union, where the temporary admissible weekly dose is of $25 \mu \mathrm{g} \cdot \mathrm{Kg}^{-1}$ live weight.

Similar results were found in works on the analysis of Oreochromis mossambicus in reservoirs in the south of Sri Lanka (Allinson et al., 2002), and also in the analysis of Silurus glanis fillets from the Lake Sir Dam in Turkey (ERDOĞRUL; ERBILIR, 2007). The results for lead found in this paper differ from those found by Adeyeye et al. (1996), where the analysis of Oreochromis niloticus muscles presented metal concentration on the ratio of $0.79 \mu \mathrm{g} \cdot \mathrm{g}^{-1}$. Oyewale and Musa (2006) have also detected the presence of lead in Oreochromis niloticus originated from the Kainji and Jebba lakes in Nigeria in the average concentration of $1 \mu \mathrm{g} \cdot \mathrm{g}^{-1}$.

\section{Conclusions}

The results found in this study show that, within the analyzed batches, no fillet samples from Oreochromis niloticus were found to be contaminated by lead. Three samples were positive for cadmium and all of the samples collected were positive for copper.

The values found for cadmium and also for copper, when compared, respectively, to the REGULATION (EC) N. $1881 / 2006$ from the European Union and to the Food Standards Australia New Zealand (2002) demonstrated that they are not dangerous to human health in that they are within the standards given by these regulations.

\section{Acknowledgements}

Special thanks to the Agriculture and Supply Secretary of Parana (SEAB) for having sponsored part of this research, as well as to the veterinarian doctor Carlos Roberto Moreira, head of the regional nucleus of SEAB, Cornelio Procopio, Parana, Brazil, for having acted as an intermediate in the communication between the University, the Sate Agriculture and Supply Secretary and the fish plants.

\section{References}

ADEYEYE, E. I. et al. Determinations of some metals in Clarias gariepinus (Curvier and Vallenciennes), Cyprinus carpio
(L.) and Oreochromis niloticus (L.) fishes in a fresh water pond and their environments. Aquaculture, v. 147, p. 205-214, 1996. doi:10.1016/S0044-8486(96)01376-2

ALLINSON, G. et al. Observations on metal concentrations in tilápia (Oreochromis mossambicus) in reservoirs of South Sri Lanka. Ecotoxicology and Environmental Safety, n. 51, p. 197-202, 2002. PMid:11971640. doi:10.1006/eesa.2001.2112

ATHANASOPOULOS, N. Flame Methods Manual GBC for Atomic Absorption. Australia: Victoria, 1994.

BASSET, J.; DENNEY, R. C.; JEFFERY, G. H. Vogel - Análise Inorgânica Quantitativa. Rio de Janeiro: Guanabara Koogan, 1981.

BEVERIDGE, M. C. M.; BAIRD, D. J. Diet, feeding and digestive physiology. In: BEVERIDGE, M. C. M.; MCANDREW, B. J. Tilapias: Biology and exploitation. Netherlands: Kluwer Academic publisher, 2000. p. 59-81.

BIRUNGI, Z. et al. Active biomonitoring of trace heavy metal using fish (Oreochromis niloticus) as bioindicator species: the case of Nakivubo wetland along Lake Victoria. Physics and Chemistry of the Earth, n. 32, p. $1350-1358,2007$.

BOLS, N. C. et al. Ecotoxicology and innate immunity in fish. Developmental \& Comparative Immunology, n. 25, p. 853-873, 2001. doi:10.1016/S0145-305X(01)00040-4

CANNON, R. M.; ROE, R. T. Livestock disease surveys: A field manual for veterinarians. Canberra: Australia Government Publishing Service, 1982.

CHASIN, A. A. M.; PEDROZO, M. F. M. O estudo da toxicologia. In: AZEVEDO, F. A.; CHASIN, A. A. M. As bases toxicológicas da ecotoxicologia. São Carlos: Inter Tox, 2003. p. 1-25.

ÇOĞUN, H. Y.; YÜZEREROĞLU, T. A.; KARGIN, F. Accumulation of copper and cadmium in small and large Nile tilápia oreochomis niloticus. Bulletin of Environmental Contamination and Toxicology, n. 71, p. 1265-1271, 2003.

ERDOĞRUL, Ö.; ERBILIR, F. Heavy metal and trace elements in various fish samples from Sir Dam Lake, Kahramanmaraş, Turkey. Environmental Monit Assessment, n. 130, p. 373-379, 2007.

FOOD STANDARDS AUSTRALIA NEW ZEALAND. The $\mathbf{2 0}^{\text {th }}$ Australian total Diet Survey: a total diet survey of pesticide residues and contaminants. 2003. Disponível em: http://www. foodstandards.gov.au/_srcfiles/Final_20th_Total_Diet_Survey.pdf Acesso em: 17 out. 2009.

GOYER, R. A.; CLARKSON, T. W. Toxic effects of metals. In: KLAASSEN, C. D. Klassen, Cassarett and Doll's toxicology: the basic science of poisons. New York: MacGrall-Hill, 2001.p. 811-867.

HUET, M. Tratado de piscicultura. Madrid: Mundi-prensa, 1983.

KUBITZA, M. Tilapia: Tecnologia e planejamento na produção comercial. Jundiaí: F. Kubtiza, 2000.

MCANDREW, B. J. Evolution, phylogenetic relationship and biogeography. In: BEVERIDGE, M. C. M.; MCANDREW, B. J. Tilapias: Biology and exploitation. Netherlands: Kluwer Academic Publisher, 2000. p. 1-28.

MESCHKAT, A. Sugestões para uma política global de desenvolvimento dos recursos da pesca interior e da aquacultura. In: MESCHKAT, A. Aquacultura e pesca em águas interiores do Brasil. Rio de Janeiro: Programa de Pesquisa de Desenvolvimento Pesqueiro do Brasil, PNUD/FAO, Ministério da Agricultura/SUDEPE, 1975. cap. 4. (PDP Documentos Técnicos, n. 9). Disponível em: <http:// www.fao.org/docrep/field/003/AC562P/AC562P04.htm>. Acesso em: 17 out. 2009.

OSTRENSKY, A.; BOEGUER, W. Psicultura: fundamentos e técnicas de manejo. Guaíba: Agropecuária, 1998. 
OYEWALE, A. O.; MUSA, I. Pollution assessment of lower basin of Lakes Kainji/Jebba, Nigeria: heavy metal status of the waters, sedments and fishes. Environmental Geochemistry and Health, n. 28, p. 273-281, 2006. PMid:16767565. doi:10.1007/s10653-0069043-3

POPMA, T.; MASSER, M. Tilápia life history and biology. Texas: Southern Regional Aquaculture Center, 1999. Disponível em: <http://www.aces.edu/dept/fisheries/education/ras/publications/ species/283fsTilapia\%20life\%20history>. Acesso em: 17 out. 2009.

PROVECTO ANALITICA. Manual de metodologias de mineralização de amostras. Campinas, 2000.

SÃO PAULO (Estado). Ministério da Agricultura, Pecuária e Abastecimento. A aqüicultura e a atividade pesqueira. 2001. Disponível em: <http://www.cnpma.embrapa.br/projetos/index. php3?sec=aquic $>$. Acesso em: 17 out. 2009.009.

STREIT, B. Bioaccumulation of contaminants in fish. In: BRAUNBECK, T.; HINTON, D. E.; STREIT, B. Fish ecotoxicology. Basel: Birkhauser, 1998. p. 353-387.

TURNER, G. F.; ROBINSON, R. L. Reproductive biology, mating systems and parental care. In: BEVERIDGE, M. C. M.; MCANDREW, B. J.
Tilapias: Biology and exploitation. Netherlands: Kluwer Academic publisher, 2000. p. 33-55.

UNIÃO EUROPÉIA. Regulamento (CE) n. 1881/2006 da Comissão, de 19 de Dezembro de 2006, que fixa os teores máximos de certos contaminantes presentes nos géneros alimentícios. Jornal Oficial Da União Européia, Bruxelas, 20 dez. 2006. Legislação 364/5. Disponível em: <http://eur-lex.europa.eu/LexUriServ/LexUriServ. do?uri=OJ:L:2006:364:0005:0024:PT:PDF>. Acesso em: 17out. 2

WORLD HEALTH ORGANIZATION - WHO. Programme Of Food Safety And Food Aid. Guidelines for predicting dietary intake of pesticides residues. World Health Organization, 1997. Disponível em: <http://www.who.int/foodsafety/publications/chem/pesticides/ en/>. Acesso em: 17 out. 2009.

WORLD HEALTH ORGANIZATION - WHO. Copper in Drinkingwater. World Health Organization, 2004. Disponível em: <http:// www.who.int/water_sanitation_health/dwq/chemicals/copper. pdf $>$. Acesso em: 17 out. 2009.

ZIMMERMMAN, S.; FITZSIMMONS, K. Tilapicultura intensiva. In: CYRINO, J. E. P. et al. Tópicos especiais em psicultura de água doce tropical intensiva. São Paulo: TecArt, 2004. p. 239-266. 